\title{
A RARE CASE: PRIMARY MUCINOUS CYSTIC NEOPLASM OF THE GALLBLADDER
}

\author{
SAFRA KESESININ PRIMER MÜSINÖZ KISTIK NEOPLAZMI: NADIR BIR VAKA
}

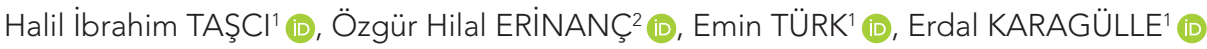 \\ 'Başkent University, School of Medicine, Department of General Surgery, Ankara, Turkey \\ ${ }^{2}$ Başkent University, School of Medicine, Department of Pathology Surgery, Ankara, Turkey
}

ORCID IDs of the authors: H.I.T. 0000-0003-2269-4798; Ö.H.E. 0000-0003-1401-6356; E.T. 0000-0003-4766-3373; E.K. 0000-0002-8522-4956

Cite this article as: Tasci $\mathrm{HI}$, Erinanc $\mathrm{OH}$, Turk E, Karagulle E. A rare case: primary mucinous cystic neoplasm of the gallbladder. $\mathrm{J}$ Ist Faculty Med 2022;85(1):133-5. doi: 10.26650/IUITFD.940494

\section{ABSTRACT}

Cystic lesions originating from the gallbladder are very rare. Mucinous cystic neoplasms of the liver and biliary system principally occur in the liver, followed by the extrahepatic biliary system. Only a few case reports were reported primarily in the gallbladder.

A 63-year-old woman was admitted to our hospital with complaints of pain in the right upper abdomen, increasing after meals, and abdominal discomfort. A laparoscopic cholecystectomy was performed. Macroscopically, the cyst was localized in the serosa of the fundus. Based on immunohistochemical examination, the cyst was diagnosed as primary mucinous cystic neoplasia of the gallbladder.

Although it is very rare, mucinous cystic neoplasia should be kept in mind when dealing with cystic lesions of the gallbladder. Due to serious associated problems such as the risk of malignant transformation or bile duct obstruction, particularly in larger cysts, a cholecystectomy is mandatory.

Keywords: Cholecystectomy, gallbladder, mucinous cystic neoplasia

\section{ÖZET}

Safra kesesinden kaynaklanan kistik lezyonlar oldukça nadirdir. Hepato-bilier sisteminin müsinöz kistik neoplazileri esas olarak karaciğerde meydana gelir ve bunu ekstrahepatik biliyer sistem izler. Primer olarak safra kesesi tutulumu olan sadece birkaç vaka rapor edilmiştir.

Karın sağ üst tarafta yemek sonrası artan karın ağrısı ve dispepsi şikayetleri olan 63 yaşında kadın hasta hastanemize başvurdu. Laparoskopik kolesistektomi yapıldı. Makroskopik olarak kist fundusun serozasında lokalize edildi ve immünohistokimyasal inceleme neticesine göre safra kesesinin primer müsinöz kistik neoplazisi olarak değerlendirildi.

Her ne kadar çok nadir görülse de, safra kesesinin kistik lezyonlarında musinöz kistik neoplaziler mutlaka akılda tutulmalıdır. Böyle hastalarda malign transformasyon ve özellikle daha büyük kistlerde safra kanalı tıkanıklığı gibi riskler nedeniyle kolesistektomi yapılması zorunludur.

Anahtar Kelimeler: Kolesistektomi, safra kesesi, müsinöz kistik neoplazi

\section{INTRODUCTION}

Cystic lesions originating from the gallbladder are very rare. Previously these have also been reported as mucinous cystadenoma, hepatobilier cyst adenom, biliary cystadenoma and mucinous cystic neoplasm (MCN) in the literature.

According to the World Health Organization MCN of the liver and biliary system is defined as the cyst-forming epitelial neoplasia, typically shows no contact with the bile ducts and consists of epithelium that produces mucin variably, from cubic to columnar (1). Cystic neoplasms and cystadenocarcinomas originating in the hepatobiliary system most commonly occur in the liver (85\% of patients) and are related with $1 \%$ of liver cystic lesions and $5 \%$ of symptomatic liver cysts (2). MCN originating from the gallbladder is very rare and constitutes only $0.02 \%$ of cases originating from the hepatobiliary system $(3,4)$.

Corresponding author/iletişim kurulacak yazar: okcu6528@gmail.com

Submitted/Başvuru: 21.05.2021 • Revision Requested/Revizyon Talebi: 15.09.2021 • Last Revision Received/Son Revizyon: 16.09.2021 • Accepted/Kabul: 29.09.2021 • Published Online/Online Yayın: 10.01.2022 
With this case report, it is aimed to present an unusual case of MCN of the gallbladder and to review the literature.

\section{CASE REPORT}

A 63-year-old woman was admitted to our hospital with complaints of pain in the right upper abdomen, increasing after meals, and abdominal discomfort. Also the patient has a past history of ovarian tumor, having an excision 16 years ago. On physical examination the patient was obese and there was atenderness in her right upper abdomen and epigastric region. An ultrasonography of the abdomen revealed that the gallbladder dimensions were normal while the wall thickness were increased and there were calculus approximately $38 \mathrm{~mm}$ diameter along with axis. The diameter of the common bile duct and intrahepatic bile ducts were normal. Laboratory findings showed that liver enzymes, bilirubins and alkaline phosphatase were also within the normal limits (Alkaline phosphatase $55 \mathrm{U} / \mathrm{L}$, gamma glutamyl transferase $28 \mathrm{U} / \mathrm{L}$, direct bilirubin $0.45 \mathrm{mg} / \mathrm{dL}$, total bilirubin $0.96 \mathrm{mg} / \mathrm{dL}$ ). Leukocyte was $8.97 \mathrm{~K} / \mu \mathrm{L}$ and C-reactive protein was 1.3 $\mathrm{mg} / \mathrm{L}$. A laparoscopic cholecystectomy was performed and the patient was discharged on the first day of the postoperative period without any complications.

Macroscopically, the cyst was localized in the serosa of the fundus, it was $1 \times 1 \mathrm{~cm}$ in diameter and demonstrated well-defined margins and contained mucinous fluid in the lumen. The inner surface of the cyst was smooth and there were no septations. In this case, the lesion had a diagnostic challenge and we needed to differentiate it from mucinous tumors of the ovary because of the past history of ovarian tumor excision which took place 16 years ago. Microscopically, the cyst was lined by mucin-producing, tall, columnar, epithelium (Figure 1). Focal areas of the cyst were denuded. Ovarian stroma was not seen. There were no atypia, pleomorphism

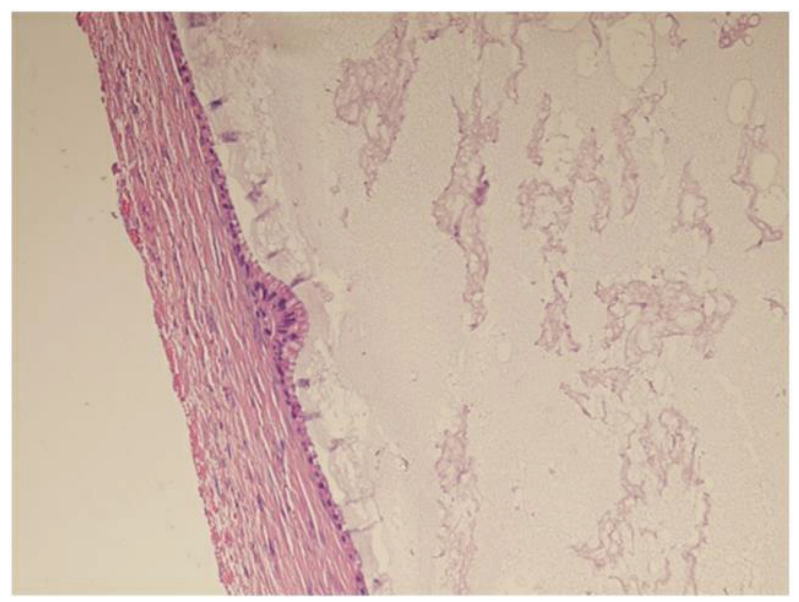

Figure 1: The figure shows the cysts are lined by flat, mucin-producing, cuboidal to columnar epithelium with basally oriented uniform nuclei. or increased mitotic activity in the epithelium. The gallbladder histology in our case showed a thickened cyst wall lined by a single layer of tall columnar nonmucin secreting cells, invagination into the underlying subepithelium was also seen. The underlying stroma showed congested blood vessels and dense fibrosis. There was no communication between the cyst and the gallbladder lumen. In immunohistochemical examination, the test for cytokeratin 7 (CK 7) was positive and cytokeratin 20 (CK 20), CDX 2, Wilms Tumor protein1 (WT 1), Pairedbox gene 8 (PAX 8) was negative.

Based on these results, the cyst was diagnosed as MCN. Thus the patient had no need for a secondary treatment.

\section{DISCUSSION}

MCN of the liver and biliary system principally occur in the liver, followed by the extrahepatic biliary system (5). Only a few case reports have been reported primarily in the gallbladder. The first case was described by Bishop in 1901, in a 40-year-old woman with a large cystic lesion in the gallbladder (6). Authors reported only 10 cases of MCN in England between 1977 and 2017 (5). A study by Devaney et al. includes $52 \mathrm{MCNs}$, of which $85 \%$ were located in the liver. Only one case $(0.02 \%)$ was in the gallbladder (1). MCNs mostly occur in women. Devaney et al. also reported that $96 \%$ of patients were women (1). Our presented case was also a 63-year-old a female patient.

The etiology of MCN is not exactly understood. One theory focuses on the relation with the congenital anomalies of the biliary tract (2). Although it is known as benign lesions, there are studies reporting the association of the malignancy and MCN as well. It is reported that MCNs have a potential risk for progression to invasive carcinoma with a rate of $30 \%(6)$.

The clinical presentation depends on the location and the size of the cyst. Patients may be asymptomatic or obstructive jaundice, abdominal pain, palpable mass, nausea and vomiting may occur. Lesions originating from the cystic duct generally lead to obstructive symptoms (5). The size of the cyst may vary from small to giant cysts reaching $30 \mathrm{~cm}$ in size (7). In the presented case, the cyst size was $1 \mathrm{~cm}$ in diameter and the cyst was asymptomatic. The patient had only symptoms related to chronic cholecystitis. As in the present case, most MCNs may be incidentally discovered.

Ultrasonography (USG) is more sensitive than computed tomography in diagnosis of the cyst. Features of the internal wall of the cyst such as septation and debris are clearly evaluated by USG (1). Tomography may be useful in defining the anatomical structure, size and spread of the cyst (1). Endoscopic retrograde cholangio pancreatography can be used for therapeutic and/or diagnostic purposes, especially in patients having obstructive icterus. In the present case, the cyst was not seen with imaging methods, 
it was found incidentally in macroscopic examination. Due to having no definite imaging criteria, it may be difficult to differentiate from cystadenocarcinoma preoperatively (2). However, nodular septations, or mural nodules, calcifications in the wall or septa may indicate malignancy (8).

Hydatid cysts and congenital cysts should be kept in mind in the differential diagnosis. Hydatid cyst can also be multi loculated, similar to MCNs. However, the wall of the hydatid cyst tends to be thicker and usually contains round or oval-shaped daughter vesicules (7). Serologic tests such as the hydatid cyst hemagglutination test may also help in the differential diagnosis. Lymphangiomas and abscess are the other cystic lesions of the gallbladder. Fine needle aspiration biopsy is not recommended for diagnosis of MCN because of the possibility of spreading into the peritoneal cavity (1).

Multilocular forms of MCN are more common than unilocular ones. The contents of the cyst may be serous, hemorrhagic, mucinous or mixed (1). Cysts are subclassified as pyloric gland, intestinal and biliary type, histologically. MCNs of the gallbladder may histologically be similar to other mucinous cysts arising from anywhere in the body and show mucin production and subepithelial ovarian-type stroma. Microscopically, they are characterized as three different layers. There is a cubic-columnar epithelium layer at the core, a mesenchymal stroma layer resembling ovarian stroma in the middle, and a hyalinized fibrous layer at the exterior (9). Immunhistochemically, estrogen and progesterone receptors may be positive, especially in MCN containing ovarian-like stroma. In addition, cytokeratin can be positive, and smooth muscle actin may also show strong reactivity (9). However, 10 to 15 percent of cystadenomas lack ovarian stroma. In the present case, ovarian stroma was not seen. Because of the patients having anamnesis of mucinous neoplasia of the ovary, immunhistochemical staining was applied to differentiate the MCN of the gallbladder from ovarian origin. Negative staining PAX 8 and WT 1 confirmed that the cyst was not of an ovarian origin.

In the treatment of gallbladder MCNs that have been diagnosed preoperatively and have no suspicion of malignancy, laparoscopic or open cholecystectomy should be performed (1). Since it is difficult to distinguish between malignant and benign lesions before surgery, the definitive diagnosis is made by histopathological examination. Surgeons should avoid perforating the cyst during cholecystectomy. We also applied a laparoscopic cholecystectomy to our patient. Surgical treatment was sufficient in the patient who had no findings suggesting malignancy on histopathological examination.
Although it is very rare, MCN should be kept in mind in treating cystic lesions of the gallbladder. Due to serious associated problems such as having the risk of malignant transformation or bile duct obstruction, particularly in larger cysts, a cholecystectomy is mandatory.

Informed Consent: Written consent was obtained from the participants.

Peer Review: Externally peer-reviewed.

Author Contributions: Conception/Design of Study- H.I.T., Ö.H.E.; Data Acquisition- H.I.T.; Data Analysis/InterpretationE.T., E.K., H.I.T.; Drafting Manuscript- H.I.T., Ö.H.E.; Critical Revision of Manuscript- Ö.H.E., E.T., E.K.; Approval and Accountability- H.I.T., Ö.H.E., E.T., E.K.

Conflict of Interest: Authors declared no conflict of interest.

Financial Disclosure: Authors declared no financial support.

\section{REFERENCES}

1. Rivero-Soto RJ, Zadeh ZH, Coleman J, Ahuja V. A mucinous cystic neoplasm originating from the gallbladder: A case report and literature review. Perm J 2019;23:18-77. [CrossRef]

2. Safari MT, Shahrokh S, Miri MB, Foroughi F, Sadeghi A. Biliary mucinous cystic neoplasm: a case report and review of the literature. Gastroenterol Hepatol Bed Bench 2016;9(Suppl1):S88-92.

3. Vogt DP, Henderson JM, Chmielewski E. Cystadenoma and cystadenocarcinoma of the liver: a single center experience. J Am Coll Surg 2005;200(5):727-33. [CrossRef]

4. Gokalp G, Dusak A, Topal NB, Aker S. Cystadenoma originating from the gallbladder. J Ultrasound Med 2010;29(4):663-6. [CrossRef]

5. Sugawara S, Hirai I, Watanabe T, Tezuka K, Kimura W. A case of mucinous cystic neoplasm of the gallbladder. Clin J Gastroenterol 2018;11(5):428-32. [CrossRef]

6. Moussa M, Douard R, Marzouk I, Kort I, Mekni A. Biliary cystadenoma and cystadenocarcinoma of the gallbladder: a clinical review. Am Surg 2017;83(6):e186-8. [CrossRef]

7. McCague A, Rosen M, O'Malley K. Laparoscopic cholecystectomy of a polypoid gallbladder cystadenoma obstructing the common bile duct. Surg Laparosc Endosc Percutan Tech 2008;18(2):209-12. [CrossRef]

8. Sharma S, Sasaki K, Allende D, Bennett A, Aucejo FN. Biliary mucinous cystic neoplasm: a classic presentation of a rare neoplasm. J GastrointestSurg 2019;23(4):874-6. [CrossRef]

9. Spector SA, Fernandez VE, Vernon SE, Dunkin B, Livingstone AS. Gallbladder cystadenoma and common bile duct obstruction. Int J Gastrointest Cancer 2003;34(23):151-5. [CrossRef] 